\title{
Albasty: A Female Demon of Turkic Peoples
}

\author{
Edina Dallos \\ Research Fellow, MTA-ELTE-SZTE Silk Road Research Group, Hungary
}

\begin{abstract}
Albasty is one of the most commonly known malevolent beings among Turkic peoples from the Altay Mountains via the Caucasus and up as far as the Volga River. This article focuses on Turkic data from the Volga region (Chuvash, Tartar, Bashkir) and the Eurasian Steppe (Kazak, Kyrgyz, Nogay, Uzbek). Various areas can be ascertained on the basis of verbal charms and folk-belief narratives. On the Eurasian Steppe, for example, Albasty was first and foremost a puerperal demon. In this territory, specialists (kuиču) were called in to keep away or oust the demon at birth. Many recorded legends and memorates concern healing methods and the process of becoming a healer. In contrast, epic texts or narratives are rarer,in the Volga region, yet there are certain verbal incantations against the Albasty, which here is rather a push or disease demon.
\end{abstract}

Keywords: Turkic beliefs, Turkic folklore texts, Turkic demonology, folklore of Inner Asia

In this paper, I will endeavour to give an overview of a mythical creature, the concept of which is widespread among most Turkic peoples. This belief has a long history and can also be evidenced in the myths and beliefs of peoples neighbouring the Turks. No other Turkic mythical beast has such extensive literature devoted to it as the Albasty. Although most relevant literature deals with the possible etymologies of the term, there are plenty of ethnographic descriptions available as well. Unfortunately, few original texts exist in the case of the latter, but there are many summaries and interpretations.

Among Turkic peoples, the daemon Albasty can be found in four large areas: on the Eurasian steppe, among Turkic peoples in Siberia, in the region of the rivers Kama and Volga, and especially in the middle and northern regions of the Caucasus Mountains. However, this daemon is not familiar to the Oguz peoples (Turkish, Azerbaijani, Turkmenian), although a similar creature is designated by other names, such as $a l$, or yarim adam.

The first part of the paper outlines the possible etymologies of the word albasty. Although it has no officially accepted etymology as of yet, the term is nevertheless ethnographically relevant.

Most Turkologists interpret albasty as a compound word, as its second part, bas-ty - 'push-ed' - can easily be understood in Turkic languages. The meaning of this word 
shows a clear semantic match with the push-daemon (incubus, succubus) function of the creature. As for the first part of the compound (al), five explanations have been proffered in print so far, several of which regard it as being of Turkic origin, while some scholars regard it as of Iranian origin. According to its Turkic etymology, al can mean 'red' (RäSENEN 1969:14); a word with the same meaning already existed in Old Turkic (Clauson 1972:120-121). This theory is reinforced by the fact that in Kyrgyz and Kazakh, there is also a kara-basty i.e. 'black-pushed' version alongside the al-basty (1888:14; Abramzon 1949:95; BaiAlieva 1972:95; ToleUbaEv 1991:47-48) - although it is only found in a few sources and may have a folk-etymological background. However, this supposition is weakened by the fact that in mythical texts referring to the albasty, the colours associated with this concept are yellow and black in almost all areas, e.g. the colour of the albasty's hair or the distinction made among the Kirghiz and Kazakh between two kinds of albasty: the more dangerous black one and the less dangerous yellow albasty (Miropiev 1888:14; KustanaEv 1894:48). However, since the $\bar{a} l$ is also an Iranian mythical concept - which can be found in several Iranian (and some Oguz-Turkic) languages (e.g. HAFNER 1986:345; JOHANSEN 1959:303) and is similar to the Turkic albasty in its function - several scholars consider the prefix al- to be of Iranian origin (ANDREev 1953:76-79; Benveniste 1960; 1953:65-74; AHMET'IANov 1981:17). We can certainly discard the suggestion that the Turkic word el, meaning 'hand', is hidden in the prefix (NASYRov 1880:251; Koblov 1910:436), as this poses serious phonological problems. Another approach takes as its starting point the Old Turkic word $a l$, meaning 'front'; thus, the name of the mythical creature would be a compound word meaning 'pushed in the front' (Ostroumov 1892:12-13; Maksimov 1876:27; NASYROV 1880:251; Koblov 1910:436). There is also the possibility of a form alp+basty (ASHMARIN 1994:I:164), where the prefix had two different early meanings in Old Turkic: 'brave/heroic', referring to humans, and 'heavy, hard, danger(ous)', referring to inanimate objects (CLAUSON 1972:127-128).

Some linguists of Iranic languages propose an entirely different starting point, the form almasty, which is not a compound word. Moreover, they regard the sound - $m$ in the second syllable as the starting point instead of the sound $-b-$. This form can indeed be found in some Turkic languages and dialects (for example in KarachayBalkar and Tuva), although far less frequently than the albasty version. ${ }^{1}$ They trace the form almasty all the way back to the ancient Babylonian form lamaštu, which would have entered Turkic languages through Iranic languages (KLIMOV - EDEL'MAN 1979:60-63; RASTORGUEVA - EDEL'MAN 2000:309). Although this proposition does not deserve to be rejected immediately, the word initial $a$ - sound of Turkic 'data' cannot be a Turkic development because an $a$ - prosthesis would never have been prefixed to a first syllable $l a$.

As for the ethnographic data regarding the albasty beast, this paper presents it from two distinct aspects. One is regional; that is to say, presented as a concept typical of specific areas on the basis of available data. In addition, the contamination of the concept by other mythical creatures will also be addressed.

\footnotetext{
1 Actually, there is indeed a $/ \mathrm{b} /-/ \mathrm{m} /$ sound alternation in Turkic languages.
} 
Among Turkic steppe peoples (Kazakh, Kyrgyz, Nogai), the term albasty essentially covers three different concepts. According to the most widespread of these, the albasty is a puerperal daemon, dangerous for mother and baby alike, one who may even cause an expectant mother's death during childbirth. Major summaries almost unanimously describe the albasty as both a long-haired and tangled-haired, large-breasted female figure who throws her breasts over her shoulders (VAlikHanov 1904:277; DyRENKova 2012:240; Kereitov 1980:122; TAIZHANOV - IsMAILOV 1986:117). In the majority of mythical stories about the puerperal daemon and protection against it, however, it usually appears in the form of an animal (dog or ram), carrying human lungs in its mouth and looking for some flowing water (river or stream) to throw the lungs into (POIARKov 1891:41; BAIALIEVA 1972:96-98). According to the belief, the albasty takes out the lungs of a woman giving birth, but the victim does not die until the daemon throws the lungs into the water. Some legends claim that the daemon can be stopped before it finds water and the mother saved (MIROPIEv 1888:9-13). Only people with special abilities are able to recognise the albasty (POIARKOv 1891:43; NAUMOVA 2016:67), and they are also able to defeat it. The albasty must be severly beaten and made to flee (Divaev 1896:43-44; BaIALIEvA 1972:97). Among the Kyrgyz and the Kazakh, the person chosen to perform this act is not always the baksi (a local word for shaman), although there are stories about an "albasty-exorcist" by that name. However, the person most suitable for this task is the one called kuис̌u (e.g. Dyrenkova 2012:233) - the word kuuču being a derivative of the verb kuu-, meaning 'drive (out), herd, expel' (Iudahin). Among the Kyrgyz, there are sources claiming that although the baksi is able to drive out the less dangerous yellow albasty (which primarily causes diseases), this does not apply to the more dangerous black albasty (the actual puerperal daemon) (BASILOv 1994:56). Only the kuиси is able to drive out the latter. Several stories (all of which are first-person accounts, some recounted by the kииси himself) talk about how someone becomes a kиисй. Almost all of these claim that it was by chance that they realised they had a special skill. For example, when they see an animal, carrying human lungs, they immediately know that it is an albasty (Miropiev 1888:10-15). This recognition is mutual, as the given albasty can also identify individuals who recognise it and are thus able to defeat it. Therefore, it sometimes happens that no fight ensues at all and the albasty does not even have to suffer a beating because as the kuиč reaches a house where a woman giving birth has just been attacked by the albasty, he merely greets those inside saying, "The hero has arrived!" causing the albasty to flee immediately (BAIALIEvA 1972:97). There is also a source mentioning that a kuиси only sent his clothes to the house where the woman was giving birth, which was enough for the birth to proceed without any problem (BAIALIEvA 1972:97; ABRAMZON 1949:99).

"There is also a story in which Suleimankul tells of how he became a kuис̌u:

One night, on my way home from a visit, I stopped behind a big poplar tree. From there I saw a great fire burning in the distance. Two albastys were playing around the fire. I went closer and they did not notice me. I grabbed one of them and started to beat it hard. It yelled in a human voice:

'I am dancing around, Suleiman Ake,

I am not going to the place

You are going! 
Let me go!'

I did not let it go and carried on beating it. Then it gave me one of its hairs. Then I let it go. That was the time I became a kuис̌u." (BAIALIEva 1972:96)

According to another belief that is prevalent on the steppes, the albasty is a push-daemon, so-called because it pushes people at night while they sleep, appearing in the form of a man or woman or, in certain cases, even an animal. In the sources, it is typically a smallsized human (about three feet tall), often with long, tangled hair (SNESAREv 1969:32; BAIALIEVA 1972:98-100). There are several beliefs concerning the albasty's hair. One of them claims that whoever obtains a strand of its hair will have power over it, as happens in the story above. Another version is that by possessing one of its hairs, the albasty can be forced to perform household chores, which it will do until its hair is returned (KEREITOV 1980:122). This concept of the albasty working around the house is not dissimilar to its third form, which has integrated some characteristics of house or stable-daemons. According to these ideas, the alpasty rides the horses at night until they foam at the mouth, and at other times plaits their manes (SNESAREV 1969:32). Among steppe-dwelling Turkic peoples, there are relatively fewer data on the latter. It is typical, however, that such an albasty cannot be defeated by beating, nor by getting hold of a strand of its hair. Instead, one must take and hide the book the albasty carries under its arm so that it cannot find it. In these stories, the book taken from the albasty brings wealth to the host (e.g. TaIzHANOv - Ismailov 1986:117).

Among Turkic people in Siberia, where the practice of shamanism continued until the first third of the $20^{\text {th }}$ century, there are in essence two related concepts about the albasty. On one hand, it is an evil spirit bringing diseases to people, mainly psychiatric diseases and insanity (ANOHIN 1924:6), and on the other, its role is related to the shaman's activity. For shamans, the albasty plays a part in diseases during their initiation, and its name also occurs among the shaman's helping spirits during their activity (VITASHEVSKII 1918:166; BASILOv 1994:59). Yakut shamans are sometimes divided into two groups, one of which is the ayï ('good, holy'), and the other is the albaasï, 'the shaman of evil spirits and devils' (KSENOFONTOV 1930:113). These characteristics sometimes also occur in the steppe areas, where certain forms of shamanism (mainly the baksys, who had a healing function) were still extant at the beginning of the $20^{\text {th }}$ century. An example of this was recorded in Horezm, which is interesting both from a linguistic and a religioethnological aspect: a professional reciter of the Koran, who was also recognised as a healer, provided information of a shaman song, the invocational part of which mentions the names of some 108 angels, spirits and saints, with the name alpasty among them (Murodov 1975:100-118). The linguistic interest of the text itself is that one part of it is in Uzbek and the other part in Tajik. These two languages are not even related to one another, Uzbek being a Turkic and Tajik an Iranic language.

In the mythology of some Siberian Turkic areas, the alpasty appears as a kind of female forest spirit who enters into a sexual relationship with men logging or hunting in the forest (DYRENKova 2012:233-234).

The Turkic peoples of the Volga-area can be divided into two large, linguistic groupings. Tartar and Bashkir belong to the Kipchak languages (just as Kazakh and Kyrgyz, already mentioned), whereas Chuvash constitutes a separate branch among Turkic languages, with numerous special characteristics. 
In the case of the Bashkirs, sources from the late $19^{\text {th }}-$ early $20^{\text {th }}$ century describe the albasty as a long-haired female daemon attacking at night, her breasts long enough for her to throw over her shoulders (LossivevsKII 1868:28; RUDENKo 2006:271). When she shoved people at night, they were unable to breathe because the albasty stuffed her large breast into the victim's mouth. A $19^{\text {th }}$-century source mentions the tearing out of one of the albasty's hairs, but here it no longer has a mythical background (LossivevsKII 1878:28). In this source, the pulled strand of hair is only the proof of the pushing that had taken place that night, and that the albasty is to blame. In the incantation used to "drive out" the albasty, mention is also made of breasts as one of the 'places' where the albasty is sent:

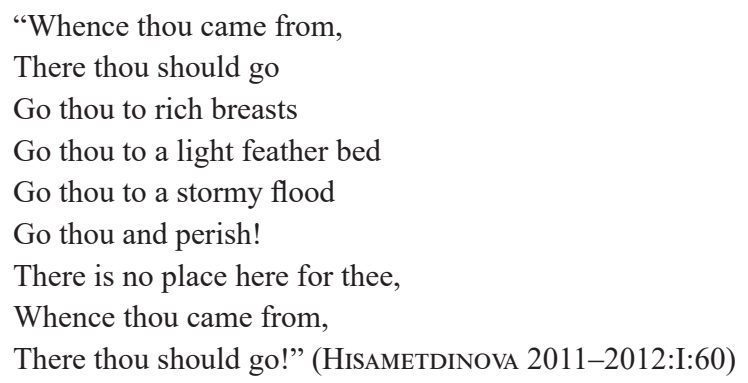

Among the 'sending-away' type of Bashkir incantations known to us, there is no other instance of 'sending to breasts'.

Unsurprisingly, stories regarding the albasty are common among Bashkirs. For example, a text recorded in 1906 describes the old woman living next door as an albasty, who appears to the little boy home alone in the form of a little girl, and who is eaten by the family dog a few days later (HisAMETDINOvA 2011-2012:I:59).

Among Tartars, the albastï is notorious as a push-daemon who shoves people at night, either in their sleep or while they are awake. During this process, the person being pushed cannot move and feels heavy pressure around their heart and a choking tightness in their throat (NASYRov 1880:269; SZENTKatolnai Bálint 1875:149; Koblov 1910:437-438). A victim can escape the assault by moving his or her little finger (NASYROV 1880:269). According to material recorded among Christian Tartars, the albastïs mainly attack at Christmas, when they knock into people from the front and push them to the ground, putting their full weight on them, thus rendering them totally immobile (MAKSIMOv 1876:27). Some Tartar sources mention that the albastïs not only push people but also suck their blood (NASYROv 1880:251), and one or two sources also say that the albasty is a creature who drives horses and generates wind (MAKsimov 1876:29). There are also several different sources regarding the physical appearance of the albasty. Here, the long-haired, large-breasted woman so typical elsewhere is not so prevalent. Some sources describe it as a human-looking figure (KoBLOv 1910:437), but there are other descriptions likening it to a large haystack (MAKSIMOv 1876:27-29).

Among the Chuvash, to whom the albasty mostly appears in incantations (RodionOv 2012:225-229), early $20^{\text {th }}$ century sources had difficulties defining what the term meant. Essentially, three different models of the creature are known (ASHMARIN 1994:I:166). One of them claims that the albasty is a kind of evil which can attach to a person and cannot be more clearly defined. Another source says that the albasty appears as a maiden 
to young lads and as a lad to maidens, and that one must not turn around when it leaves. If someone does so despite the prohibition, the albasty says "Do not tell anyone!" and assaults the person. Although the source is rather vague here, it might be related to the idea that the albasty only appears to be human from the front and has no back, leaving its entrails visible. Such a belief exists among the Tuva as well, where a creature appears as a boy to girls and as a girl to boys (KATANOv 1893:522). The albasty might have been infamous among the Chuvash ${ }^{2}$ as a push-daemon, also referred to by some sources. If a person experienced intense pain in their bones or "was pushed" at night, even if this was attributed to the evil spirit by the name of usal, the alpastă incantation had to be employed. It is clear from the text of the incantation that the albasty can now only be interpreted as an evil spirit - one which is hard to describe and which appears in many different compounds:

"Wind alpastă /alpasti ${ }^{3}$
wealth alpasti
water alpasti
fiery alpasti
fiery xayar
fiery sexmet
fiery usal
returns to the meeting
dog alpasti
chicken alpasti
beast ${ }^{4}$ alpasti
bath alasti
wind's văpăr
sun's văpăr
water's văpăr
dead man's văpăr
house văpăr
beast ${ }^{5}$ văpăr
money văpăr
fiery văpăr
fiery sexmet
fiery xayar
fiery usal
returns to the meeting
between Pitěr and Moscow

2 Chuvash: alpastă.

3 The word alpasti may be the third person singular, genitive form of alpastă, but in the present-day spoken Chuvash language, the word form alpasti also occurs (so it can also be a nominative case). Both possibilities are acceptable, as alpasti also occurs where it is certainly not a genitive case, for example: vutlă alpasti (fiery or fire alpasti), whereas below in parallel structures, certainly genitive case forms of văpăr occur (văpri).

4 The Chuvash word kayăk refers to all non-domesticated beasts and birds.

5 Non-domesticated animals (Chuvash kayăk). 
there is a twelve-year-old girl,

go thou there!

Do not debate!

Do not contradict!” (AsHMARIN 1994:1:166)

Of the other evil spirits in the incantation, the usal and the sexmet indicate 'bad, disease, difficulty, trouble', and vupăr is fundamentally a nocturnal push-daemon as well as the name of the witch in fairy-tales.

Because of the traditions above, it may also be worth noting that in present-day spoken Chuvash language, the word alpastă denotes somebody that has unkempt hair or a generally untidy appearance (SKVORTSOv 1982:31).

As a conclusion to this paper, it is important to note that some mythical creatures have either been mixed up with the albasty or show great similarities to it.

One of these sources mentions a creature not yet discussed here, typical in Turkish language areas, the yarm adam, which denotes 'half-human'. In Turkish, this is a puerperal daemon and also one that brings diseases to children, displaying a great likeness to the figures Lamaštu-Lilith-Gello, which are of Babylonian origin but are also recognised in South-Eastern Europe and in European Jewish beliefs. According to the story, Suleiman (Solomon) wanted to cast a yarım adam, which brought diseases to young children, into the fire. Responding to its cries for mercy, Suleiman settled for the following agreement: in the houses where Suleiman's prayer and the names of the 12 and a half yarlm adam are written, the yarm adams will harm neither the host, nor his wealth, nor the cradle (MÉszÁros 1906:26).

This parallel is especially interesting because the Bashkirs also recognise a halfhuman mythical creature called yarimtig, who is basically a forest spirit. In an early twentieth-century source, however, the yarimtiq is described as a hairy creature with the ability of seeing into the future and a love for riding horses; not just riding them, in fact, but mercilessly so until they foamed at the mouth. According to several scholars, in the Bashkir language the name yarïmtïq is only widespread in certain areas and is identical to the forest daemon called šürale in other places. The name of the Bashkir šürale also exists in the Kazakh language (sorel) and, according to some sources, this forest daemon is the albasty's husband (VALIKHANOv 1904:277). The name "half-human", on the other hand, can be related to the creatures that only appear to be human from the front, but which in fact seem only half-human as they have no backs, rendering their innards visible.

When studying both steppe Turks and Bashkirs, several scholars have identified the mythical creature called "yellow (or blond) girl" (sarï qïz) with the albasty. The reason for this identification could be that the albasty is a yellow-haired or blond-haired creature. However, this identification is not satisfying, even though the two creatures do indeed have similar features. The sari qïz primarily appears in shamanic songs in the texts of steppe Turkic peoples as one of the spirits assisting the shaman (e.g. Divaev 1899:314; VERBITSKII 1893:55) but is not widespread either as a pusher or a puerperal daemon. 


\section{REFERENCES CITED}

ABramzon, Saul

1949 Rozhdenie i detstvo kirgizskogo rebenka [Birth and Childhood of the Kyrgyz Child]. Sbornik Muzeia Antropologii i Etnografii XII:78-138.

Ahmetianov, Rifkat

1981 Obshchaia leksika dukhovnoi kul'tury narodov srednego povolzhia [General Vocabulary of the Spiritual Culture of the Peoples of the Middle Volga]. Moskva: Nauka.

ANDREEv, Mihail

1953 Tadzhiki doliny Huf (verhovia Amu-Dari) [Tajiks of the Huf Valley (upper Amu Darya)]. Vyp. 1. Stalinabad: AN Tadzhikskoi SSR.

ANOHIN, Andrei

1924 Materialy po shamanstvu u altaitsev [Materials on Shamanism among Altaians]. Leningrad: Izdatel'stvo Rossiiskoi Akademii Nauk. (Sbornik Muzeia Antropologii pri Rossiiskoi Akademii Nauk IV/2.)

ASHMARIN, Nikolai

1994 Slovar' chuvashskogo jazyka [Dictionary of the Chuvash Language]. I-XVII. Cheboksary: Russika.

BaIALIEVA, Toktobiubiu

1972 Doislamskie verovaniia $i$ ikh perezhitki u kirgizov [Pre-Islamic Beliefs and Their Remnants among the Kyrgyz]. Frunze: Ilim.

BASILOV, Vladimir

1994 Albasty. In Petruhin, V. La (ed.) Istoriko-etnograficheskie issledovaniia po fol'kloru. Sbornik statei pamiati Sergeia Aleksandrovicha Tokareva, 49-76. Moskva: Vostochnaia Literatura.

Benveniste, Émile

1960 Le dieu Ohrmazd et le démon Albasti' [The God Ohrmazd and the Demon Albasty]. Journal Asiatique 248:65-74.

Clauson, sir Gerard

1972 An Etymological Dictionary of Pre-Thirteenth-Century Turkish. Oxford: Clarendon Press.

Divaev, Abubakir

1896 Etnograficheskie materialy [Ethnographic Materials]. Sbornik materialov dlia statistiki Syr-Dar'inskoi oblasti 5:1-60.

1899 Materialy. A.) Etnograficheskie. Iz oblasti kirgizskikh verovanii. Baksy, kak lekar' i koldun [Materials. A.) Ethnographic. From the Field of Kyrgyz Beliefs. Baksy as a healer and a sorcerer]. Izvestiia Obshchestva Arheologii, Istorii i Etnografii 15(3):37-341.

DyRENKova, Nadezhda

2012 Albassty v religioznykh predstavleniiakh i fol'klore turetskikh plemen [Albassty in Religious Beliefs and Folklore of Turkic Tribes]. In Dyrenkova, Nadezhda Petrovna - SchöNIG, Claus (eds.) Tiurki Saiano-Altaia. Stat'i i etnograficheskie materialy, 230-244. Sankt-Peterburg: Nauka.

HAFNER, Amira

1986 Al. In Bearman, Peri J. (ed.) Encyclopaedia of Islam I. Leiden: E. J. Brill. 
HisAmitdinova, Firdaus

2011-2012 Slovar'bashkirskoi mifologii [Dictionary of Bashkir Mythology]. I-III. Ufa: IIJaL UNC. RAN.

IUDAHIN, Konstantin

(1985) Kirgizsko-russkii slovar' [Kyrgyz-Russian Dictionary]. Frunze: Sovetskaia Enciklopediia.

JOHANSEN, Ulla

1959 Die Alpfrau. Ein Dämonengestalt der türkischen Völker [Succubus. A Demonic Figure of the Turkic Peoples]. Zeitschrift der Deutschen Morgenländischen Gesellschaft 109:303-316.

KaTANOV, Nikolai

1893 Sredi tiurkskikh plemen [Among the Turkic Tribes]. Isvestiia Imperatorskago Russkago Geograficheskago Obshchestva 29(6):519-541.

KereItov, R. H.

1980 Mifologicheskie personazhi traditsionnyi verovanii nogaitsev [Mythological Figures of Traditional Nogai Beliefs]. Sovetskaia etnografiia 1980(2):117-129.

Klimov, Georgii - Edel'man, Dzhoi

1979 K etimologii Albasty/Almasty [To the Etymology of Albasty/Almasty]. Sovetskaia tiurkologiia 1979(3):57-63.

KoBlov, Jakov

1910 Mifologiia kazanskikh tatar[Mythology of Kazan Tatars]. Izvestiia obshchestva arkheologii istorii i etnografii 26(5):415-470.

KSENOFONTOV, Gavriil

1930 Legendy i rasskazy o shamanakh u iakutov, buriat $i$ tungusov. Izdanie vtoroe, dopolnennoe $i$ pererabotonnoe [Legends and Stories about the Shamans of the Yakuts, Buryats and Tungus. Second Edition, Revised and Revised]. Moskva:Bezbozhnik.

Kustanaev, Hudabai

1894 Etnograficheskie ocherki kirgiz Perovskogo i Kalinskogo uezdov [Ethnographic Essays of the Kyrgyz Perovsky and Kalinsky Counties]. Taškent: O. A. Porcev.

LosSIEVSKII, Mihail

1868 Iz sueverii i legend musul'man Orenburgsogo kraia [Some Superstitions and Legends of Muslims of the Orenburg Region]. Orenburgskii listok № 36: 26-30.

Maksimov, Semen

1876 Ostatki iazychestva $v$ sovremennykh verovaniiakh kreshchennykh tatar kazanskoi gubernii [The Remnants of Paganism in the Present-day Beliefs of the Baptized Tatars of the Kazan Province]. Kazan': Tip. Imperatorskogo Universiteta.

MÉSZÁROS, Gyula

1906 Az oszmán török nép babonái I. [Ottoman Turkish Supertitions]. Ethnographia $17: 20-32$.

Miropiev, Mihail

1888 Demonologicheskie rasskazy kirgizov [Kyrgyz Stories about Demons]. SanktPeterburg: Tip. Kiršbauma. 
Murodov, Otabek

1975 Shamanskii obriadovyi fol'klor u tadzhikov srednei chasty doliny Zeravshana [Shamanistic Ritual-folklore among Tajiks in the Middle of Zerafshan Valley]. In Snesarev, Gleb Pavlovich - Basilov, Vladimir Nikolaevich (eds.) Domusulmanskie verovaniia i obriady v Srednei Azii, 91-122. Moskva: Nauka.

NASYRov, Kaiium

1880 Poveria i obriady kazanskikh tatar [Beliefs and Rites of the Kazan Tatars]. Zapiski imperatorskago russkago geograficheskago obshchestva 6:239-270.

NAUMOVA, Iuliia

2016 Demonologicheskii personazh albasty v rodil'noi obriadnosti kazakhov: funktsii i atributy [Demonological Character of Albasty in the Birth Ceremony of Kazakhs: Functions and Attributes]. Vestnik RGGU 12(21):65-71.

Ostroumov, Nikolai

1892 Tatarsko-russkii slovar' [Tatar-Russian Dictionary]. Kazan': Tipografiia Imperatorskogo Universiteta.

PoIARKov, Fedor

1891 Izoblastikirgizskikh verovanii [About Some Kyrgyz Beliefs]. Etnograficheskoe obozrenie 11(4):1-43.

RÄSÄNEN, Martti

(1969) Versuch eines etymologischen Wörterbuchs der Türksprachen [Attempt of an Etymological Dictionary of Turkic Languages]. Helsinki: SuomalaisUgrilainen Seura.

Rastorgueva, Vera - Edel'Man, Dzhoi

2000 Etimologicheskii slovar' iranskikh iazykov [Etymological Dictionary of Iranian Languages]. Tom. I. Moskva: Vostochnaia literatura.

RoDionov, Vitalij

2012 Čăvaš xalăx pultarulăxě. [Chuvash Folk Poetry]. Šupaškar: Čăvaš Kenekĕ.

RuDENKO, Sergei

(2006)Bashkiry. Istoriko-etnograficheskie ocherki [Bashkirs. Historical and Ethnographic Essays]. Ufa: "Kitap".

Skvortsov, Mihail

1982 Čăvašla-vïrăsla slovar' [Chuvash-Russian Dictionary]. Moskva: Russkii iazyk.

SNesarev, Gleb Pavlovich

1969 Relikty domusul'manskikh verovanii i obriadov u uzbekov Khorezma [Relics of Pre-Islamic Beliefs and Rites among Uzbeks of Khorezm]. Moskva: Nauka.

SzEnTKATOLNAi BÁLINT Gábor

1875 Kazáni-tatár nyelvtanulmányok I. Kazáni-tatár szövegek [Linguistic Studies of Kazan-Tatar Language I. Kazan-Tatar Texts]. Budapest: Magyar Tudományos Akadémia.

Taizhanov, K. G. - Ismailov, G. I.

1986 Osobennosti doislamskikh verovanii u uzbekov-karamurtov [Features of Pre-Islamic Beliefs among the Karamurt Uzbeks]. In BAsILOV, Vladimir Nikolaevich (ed.) Drevninie obriady verovaniia i kul'ty narodov Srednei Azii, 110-138. Moskva: Nauka. 
Toleubaev, Abdesh

1991 Relikty doislamskikh verovanii v semeinoi obriadnosti kazakhov (XIX nachalo $X X$ v.) [Relics of Pre-Islamic Beliefs in the Family Rituals of the Kazakhs ( $19^{\text {th }}-$ Beginning of the $20^{\text {th }}$ Century)]. Almaty: Gylym.

VALIKHANOV Chokan

(1904)Sochenenija Chokana Chingisovicha Valikhanova. [Works of Chokan Chingisovich Valikhanov] (Red.: VeselovsKaGo, N. I.). S-Peterburg. (Zapiski Imperatorskago Russkago Geograficheskago Obšchestva po otdelniiu etnografii XXIX.)

VERBICKII, Vasilii

1893 Altaiskie inorodtsy [Altaian Foreigners]. Moskva: Levenson.

VITASHEVSKII, Nikolai

1918 Iz nabliudenii za iakutskimi shamanskimi deistviiami [About some Observations of Yakut Shamanistic Actions.]. Sbornik muzeia antropologii $i$ etnografii 5(1):165-184.

Edina Dallos graduated from the University of Szeged as a Turkologist in 1996. She completed her PhD degree in Budapest (Eötvös Loránd University) in folkloristics and cultural anthropology in 2004. Earlier, her main area of research was the folklore (folk tales and beliefs) of Turkic peoples in the Volga region (Tartars, Bashkirs and Chuvashes). Since 2017, she has been researching the early religious patterns (shamanism and tengrism) of Turkic peoples as a research fellow of the MTA-ELTE-SZTE Silk Road Research Group. E-mail: dallosedina@hotmail.hu

Open Access. This is an open-access article distributed under the terms of the Creative Commons Attribution 4.0 International License (https://creativecommons.org/licenses/by/4.0), which permits unrestricted use, distribution, and reproduction in any medium, provided the original author and source are credited, a link to the CC License is provided, and changes - if any - are indicated. (SID_1) 
